\title{
Entendiendo el Partido Arquitectónico de un Rascacielos, basado en sus Flujos, su Forma, Contexto Urbano e Integración Estructural
}

\author{
Ciudad de México. México
}

\author{
UNDERSTANDING A SKYSCRAPER FLOW \\ Mexico City, Mexico
}

\section{Romano, L. Benjamín}

LBR\&Arquitectos. bromano@lbr.com.mx

Área Construida / Constructed Area: $89657 \mathrm{~m}^{2}$ · Toneladas de acero estructural / Structural Steel Tons: 9502 toneladas; (105,98 kg/m²) - Consumo de Energía Diseñado / Designed Energy Consumption: $4551 \mathrm{~kW}$. Demanda de energía neta de $2731 \mathrm{~kW} \cdot$ Capacidad mecánica / Mechanical capacity: 1508 Toneladas de refrigeración/Refrigeration Tons (18.096.000 BTU) · Aguas residuales hasta el drenaje / Waste water to drainage: 0 - Eficiencia energética total / Total Energy Efficiency: - 25,4\% · Aparcamiento (Código de la ciudad) / Car Parking (City code): 1100 unidades / units.

https://doi.org/10.4995/CIAB8.2018.7896

Resumen: El documento analiza a la Torre Reforma desde su parte arquitectónica, basada en la eficiencia del flujo, del confort humano y del contexto urbano. También analiza las razones por las que el proyecto rompe con toda una generación de edificios altos, forrados tradicionalmente con fachadas acristaladas.

Palabras clave: Rascacielos; Flujos; Forma; Contexto urbano; Integración Estructural.
Abstract: The document analyses the Torre Reforma skyscraper from its architectural part to its final form, based on its flow efficiency, human comfort, and the immediate urban context. It also analyses the rationale that leads the project to break away from a generation of all-glass façade buildings.

Key words: Skyscraper; Flow; Forma; Urban Context; Structural Integration. 

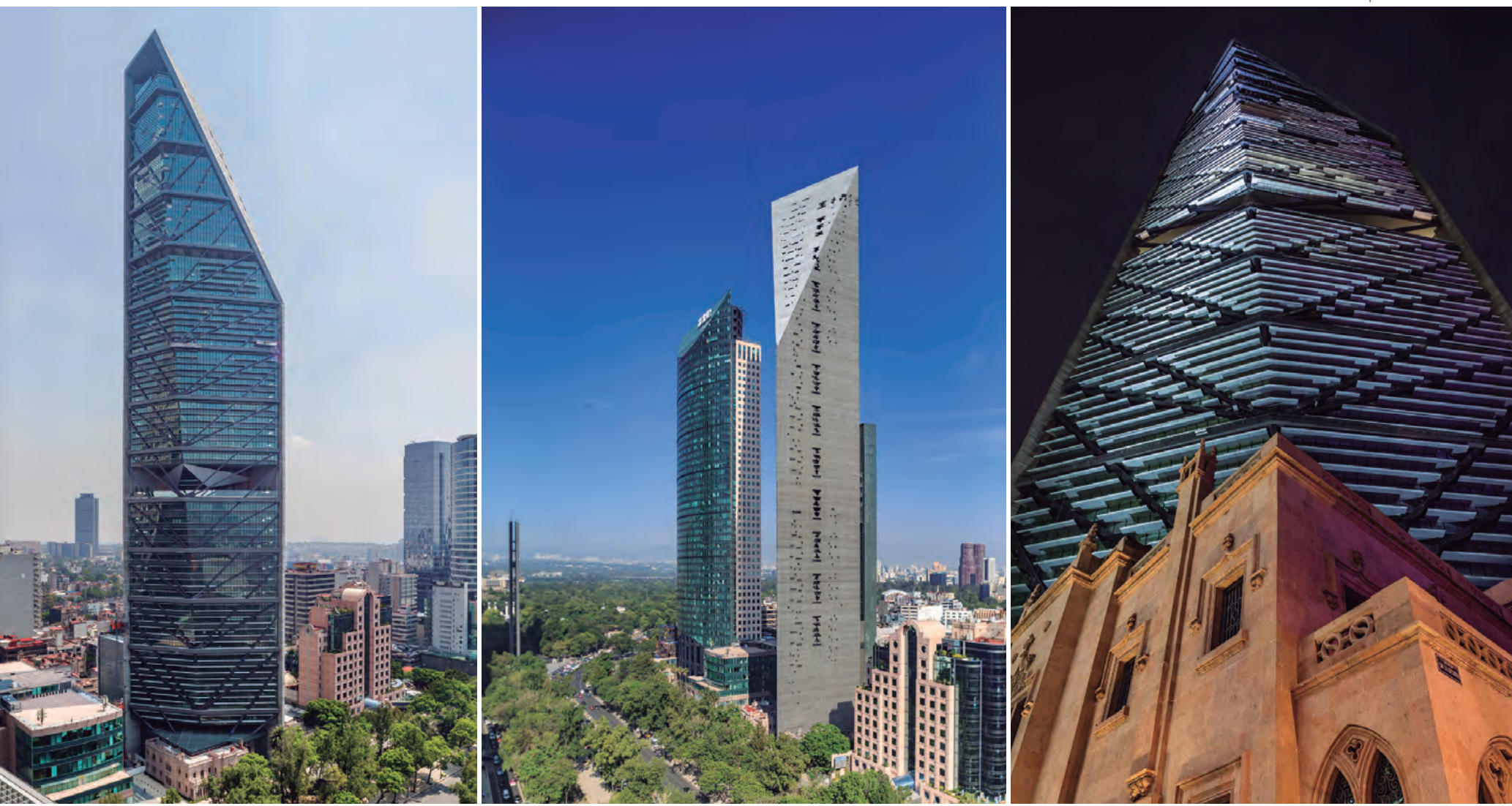

Figura 1. Imagen Urbana. Alfonso Merchand (2016). CLBR\&A / Figure 1. Urban Image. Alfonso Merchand (2016). CLBR\&A.

\section{Introducción}

La Torre Reforma (Fig. 1), diseñada por Benjamín Romano, se completó en 2016. Además de ser el edificio más alto de la Ciudad de México, es también un icono de innovación y liderazgo en la industria de edificios de gran altura, que ha comenzado a romper con una generación de fachadas de cristal.

Una adecuada planificación de los flujos en el edificio, le permitió lograr una reducción del 25,4\% en el consumo de energía, cero drenaje hacia la ciudad, una considerable reducción del 30\% en el consumo de agua potable y un reducido presupuesto para la construcción del edificio.

La influencia de la arquitectura prehispánica y colonial mexicana se evidencia en las sólidas fachadas estructurales y arquitectónicas de concreto expuesto, donde la tectónica es considerada para afrontar la histórica sismicidad de la Ciudad de México.

El análisis adecuado de los flujos que interactúan en el edificio es clave para el entendimiento del proyecto, que se encuentra desplantado en un pequeño predio (en relación con la altura del edificio). La Torre Reforma recibió la Medalla de Oro en la Bienal de Arquitectura 2016

\section{Introduction}

Torre Reforma (Fig. 1) designed by architect Benjamin Romano, was completed in 2016. In addition to being the tallest building in Mexico City, it is also an icon of innovation and leadership in the high-rise building industry, which has begun to break away from a generation of all-glass facades.

A proper planning of the flows in the building allowed it to achieve a $25.4 \%$ reduction in energy consumption, zero drainage to the city, a considerable $30 \%$ reduction of potable water, and a manageable budget for a high-rise building, designed within a small parking lot (in relation to the building height).

The influence of Pre-Hispanic and colonial Mexican architecture is revealed in the solid concrete structural and architectural façades, where tectonic materials are predominantly used to address the local seismic history.

The proper analysis of the flows that interact in the building is key to understand the complexity of the project, which was awarded the Gold Medal in the 2016 Architectural Biennale. 


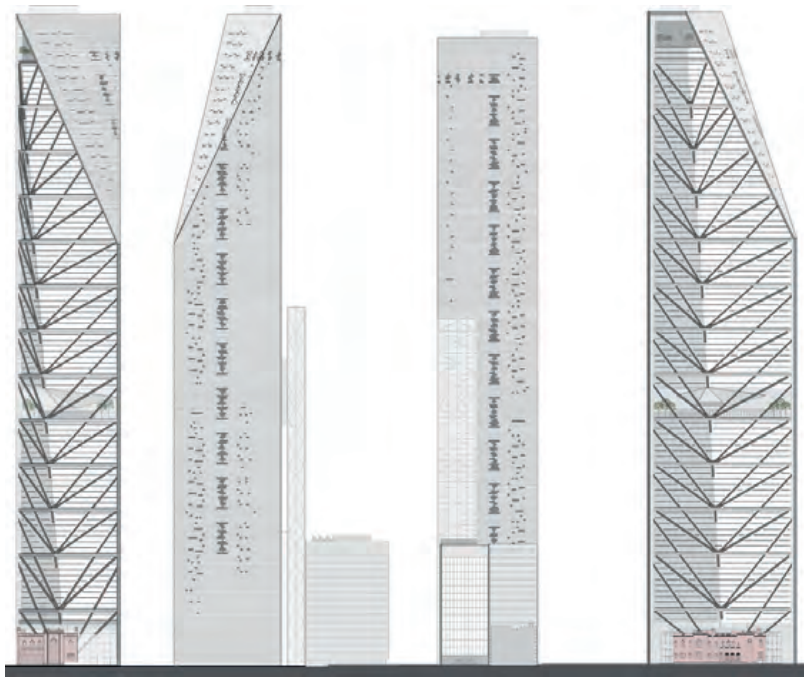

Figura 2. Fachadas. Arq. L. Benjamín Romano (2016). OLBR\&A / Figure 2. Facades. Arch L. Benjamín Romano (2016). CLBR\&A.

\section{Discusión}

Para la definición del partido arquitectónico se deben considerar los diferentes elementos que permiten su definición: sitio y programa, exposición al viento y al sol, luz, visuales desde y hacia el sitio, así como los diferentes flujos que coexistirán en el edificio, ya que todos ellos influirán en el partido gobernante que define al proyecto. Los críticos arquitectónicos consideran que una buena comprensión e interpretación del partido arquitectónico es sinónimo de un buen espacio habitable, de una integración exitosa en el contexto urbano, y de buenos y equilibrados flujos en el edificio.

A este respecto, es importante aclarar que existen flujos de diversas naturalezas para el proyecto arquitectónico. Estos pueden ser: los flujos estructurales, que llevan la carga a través del edificio al suelo, los flujos peatonales o vehiculares, de energía, telecomunicaciones, agua, residuos o drenaje, solar, y Viento. Cuando los flujos se amalgaman correctamente en el espacio, el volumen resultante adquiere inevitablemente una escala lógica y proporcional, con una estética y personalidad únicas, que algunas personas describen como bellas y funcionales (Fig. 2).

La importancia de un adecuado flujo diseño de los flujos en un espacio, se puede entender fácilmente si analizamos los flujos de un ser vivo. En el caso del cuerpo humano por ejemplo, la complejidad e individualidad de las trayectoria de los diferentes flujos (producto de la evolución -iteraciones- de las especies), pueden darnos un ejemplo de lo importante que es el diseño exitoso del flujo en los edificios. Es interesante ver en nuestros cuerpos la coexistencia del flujo óseo (estructural) con el flujo de las sensaciones, de la sensibilidad o comunicación, claramente separado de las funciones

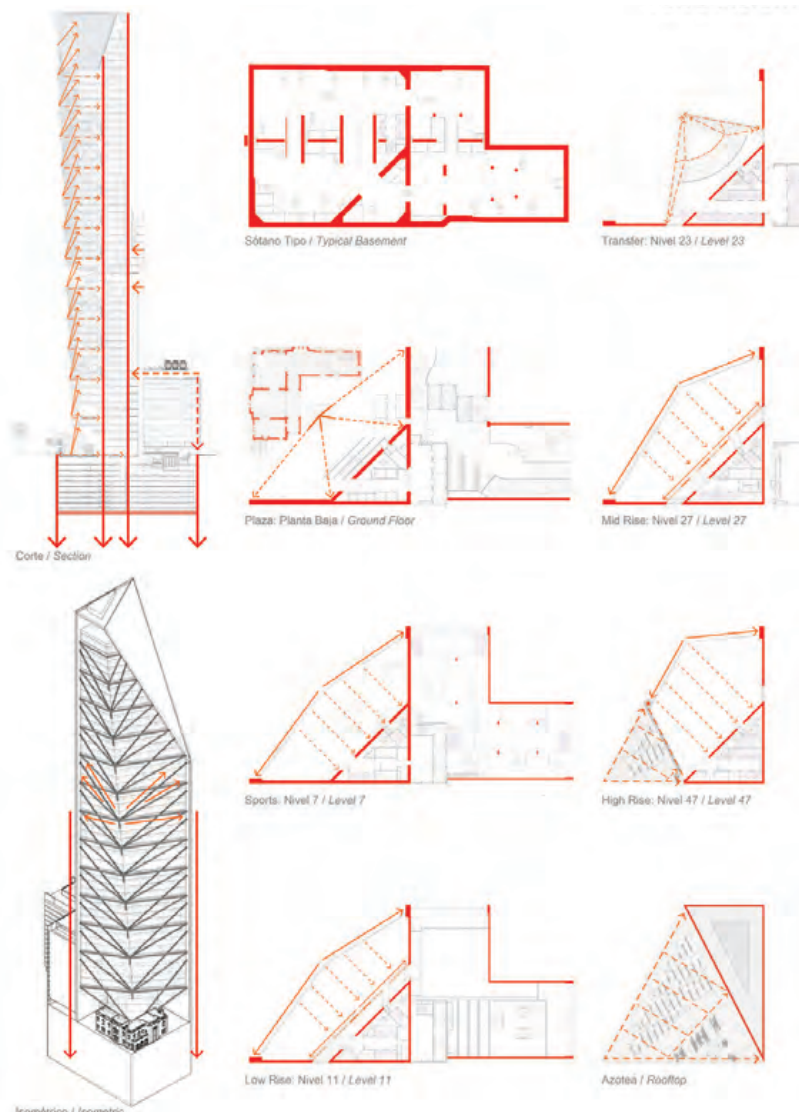

Figura 3. Flujo Estructural. L. Benjamín Romano (2016). OLBR\&A / Figure 3. Structural Flow. L. Benjamín Romano (2016). CLBR\&A.

\section{Discussion}

An in-depth analysis of the different elements that make up the project has to be considered to give definition to architectural concept: site and program, wind and sun exposure, light, visuals to and from the site, as well as the different flows that will co-exist in the building, as they all influence the governing party for the project to be developed. Critics consider that a good understanding and interpretation of an architectural concept is synonymous with a good liveable space, a successful integration into the urban context, and good and balanced flows in the building.

In this regard, it is important to clarify that there are flows of various natures at work for the architectural concept: the flows leading the load throughout the building into the soil, the pedestrian or vehicular, energy, telecommunications, water, waste or drainage, solar, mechanical or natural wind. When the flows are correctly amalgamated in the space, the resulting volume inevitably acquires a logical and proportional scale, with a unique aesthetic and personality, which some people describe as beautiful and functional (Fig. 2).

The importance of a properly designed flow within a space can be easily understood if we analyse the flows inside a living being. In the case of the human body, for instance, the complexity and individual 

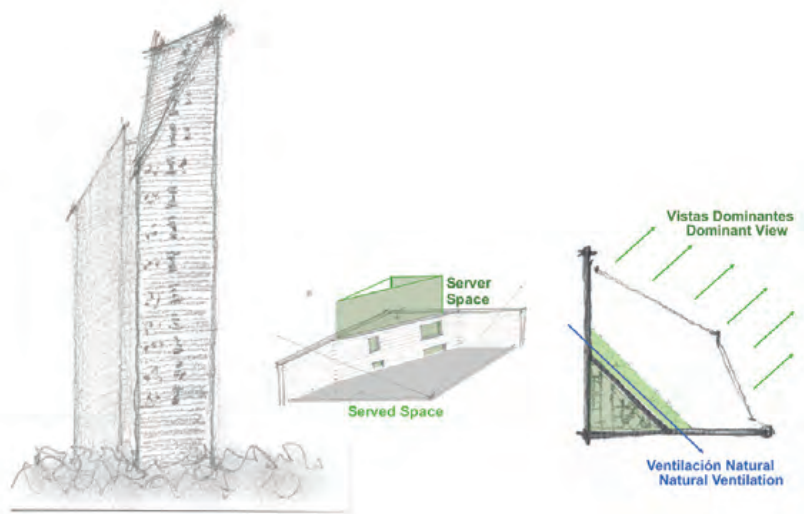

Figura 4. Croquis Esquemático. L. Benjamín Romano (2016). CLBR\&A / Figure 4. Schematic Sketch. L. Benjamín Romano. (2016). (OLBR\&A.

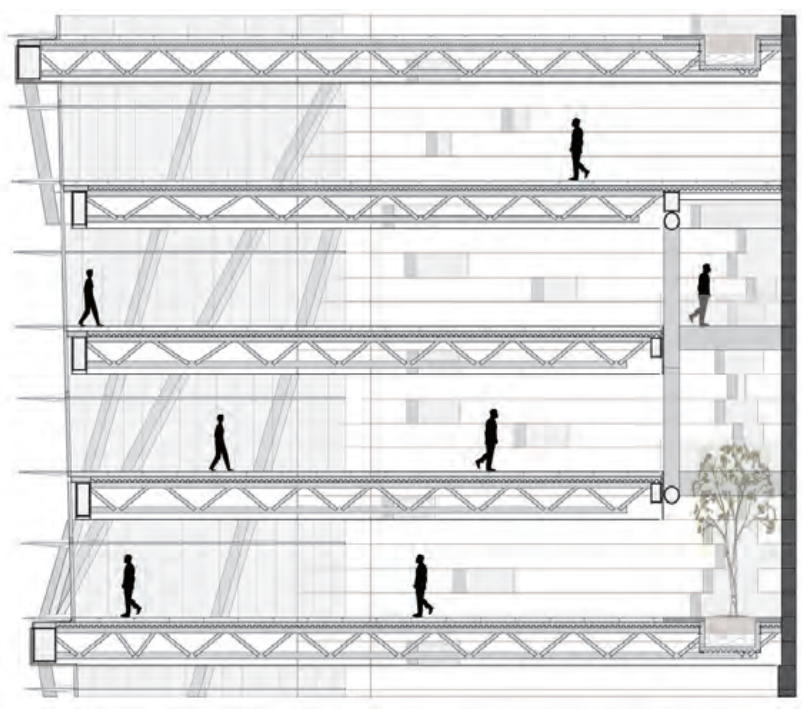

Figura 5. Patios Ajardinados. L. Benjamín Romano. (2016). @LBR\&A / Figure 5. Mexican Patios. L. Benjamín Romano (2016). CLBR\&A. alimenticias o de desechos, la oxigenación o la actividad química de nuestro cuerpo. Todos fluyendo en una coordinación e individualidad maravillosa. Cuando existe una malformación natural o accidental, la funcionalidad corporal inevitablemente se degrada, causando una mala calidad de vida, con un posible deterioro de la imagen física. En el ámbito arquitectónico, cuando los elementos estructurales de un edificio no son lógicos, cuando los usuarios no fluyen adecuadamente en el espacio, o cuando la trayectoria de los flujos tiene problemas operativos, se considera que es un edificio malformado.

En nuestra continua búsqueda por imitar a la naturaleza y/o a los elementos cotidianos de la vida para aplicarlos a soluciones arquitectónicas, entendimos que el partido arquitectónico de la Torre Reforma, debía estar definido por tres muros de concreto expuesto, dispuestos en forma de libro abierto, con un canal vertebral en la parte posterior, diseñado para alojar al espacio servidor. Este canal permite a los flujos del edificio funcionar correcta e individualmente, claramente separado del espacio servido (espacio habitable), que se encuentra ubicado al frente del edificio, por tomar ventaja de las vistas dominantes que hay hacia el Bosque de Chapultepec. Estos muros; dan forma al edificio, conforman y contienen el volumen, soportan el peso de la estructura, toman gran parte de los esfuerzos sísmicos, y transmiten la carga del edificio al suelo a través de los mismos muros que se empotran en el suelo, trabajando como elementos de cimentación por fricción. La tercer fachada está formada por 14 pares independientes de tensores que transmiten la carga hacia los muros portantes del edificio, dando forma a la estructural diagonal (Structural Diagrid). El sistema de los tensores diagonales es responsable de los movimientos horizontales en la fachada acristalada, dando forma al mismo número de clústeres 4 niveles cada uno. La individualidad de los tensores diagonales trajectory of the different flows (a product of the evolution-iterations - of the species), can give us an example of how important a successful flow design is for a building. For example, it is interesting to see the coexistence of the bone structural flow with sensational, sensitivity, and communications flow in humans, clearly separated from food or debris, oxygenation, or chemical functions. All these elements flow throughout the body in a wonderful coordination. When a natural or accidental malformation exists, the body's functionality will inevitably degrade, causing a poor quality of life, with a possible deterioration of the physical image. In the architectural field, when the structural elements of a building are not logical, when users do not flow properly in the space, or when the MEP flow trajectory has operational problems, it is considered a faulty building.

Our search to emulate nature and/or the everyday elements of life to apply to architectural solutions, lead us to understand the Torre Reforma concept, which was defined with three exposed concrete walls, arranged like an open book with a vertebral channel at the rear (server space). This channel allows the flow to work properly, separate from the liveable space (served space) that widely faces Chapultepec Park. These walls shape the building and give it volume, contain the space, support the weight of the structure, allow the building to behave adequately in seismic stresses, and transmit the building load into the ground through the same elements, working as embedded slurry walls, which are the unique foundation of the building (by skin friction). The third façade is formed with fourteen pairs of tensioned steel elements, which transport the load to the bearing walls, while conforming the structural diagrid. The 14 tensional steel elements diagrid system is responsible for the horizontal and vertical stresses at the third façade, giving form to the same number of clusters (4 levels each). The individuality of the diagrid tensors allows the third façade to twist, searching for the 
330

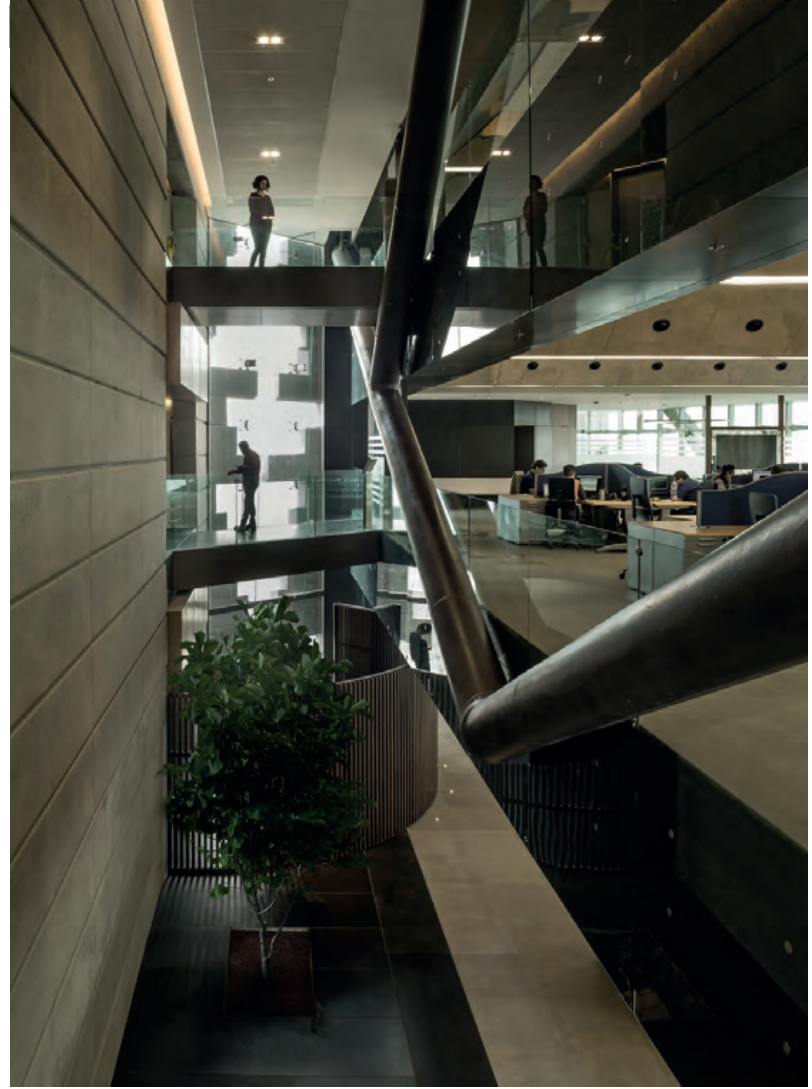

Figura 6. Patios Ajardinados. L. Benjamín Romano. 2016. LBR\&A @ / Figure 6. Mexican Patios. L. Benjamín Romano. 2016. LBR\&A @.

permite que ésta fachada se rote en búsqueda de las mejores vistas hacia el Bosque de Chapultepec, permitiendo a la vez aumentar el área rentable de los pisos superiores. Este giro en la fachada genera un voladizo de14 metros sobre la casona catalogada que rodea al lobby principal (Fig. 3).

Para preservar la casona catalogada, fue necesario desplazarla temporalmente 18 metros, con el fin de obtener una mejor área en los sótanos del edificio para satisfacer la desproporcionada demanda local de estacionamientos. La claridad y fuerza de los elementos arquitectónicos permiten al proyecto incorporar el diseño espacial y funcional del edificio en un solo concepto, definido únicamente por los tres grandes muros, con una clara separación de los espacios servidos y servidores (Fig. 4).

El espacio servido, con sus impresionantes vistas hacia el Bosque de Chapultepec, cuentan con una espacialidad única por la carencia de columnas estructurales. La falta de columnas permite a los usuarios una libre adaptación del espacio de oficinas y de las instalaciones deportivas y comerciales del edificio. Para Benjamín Romano, la eliminación de las columnas en sus proyectos ha sido una constante del trabajo realizado, logrado por el entendimiento de las fachadas como elementos estructurales y no como fronteras entre interior y exterior con grandes y estériles cargas a la estructura.

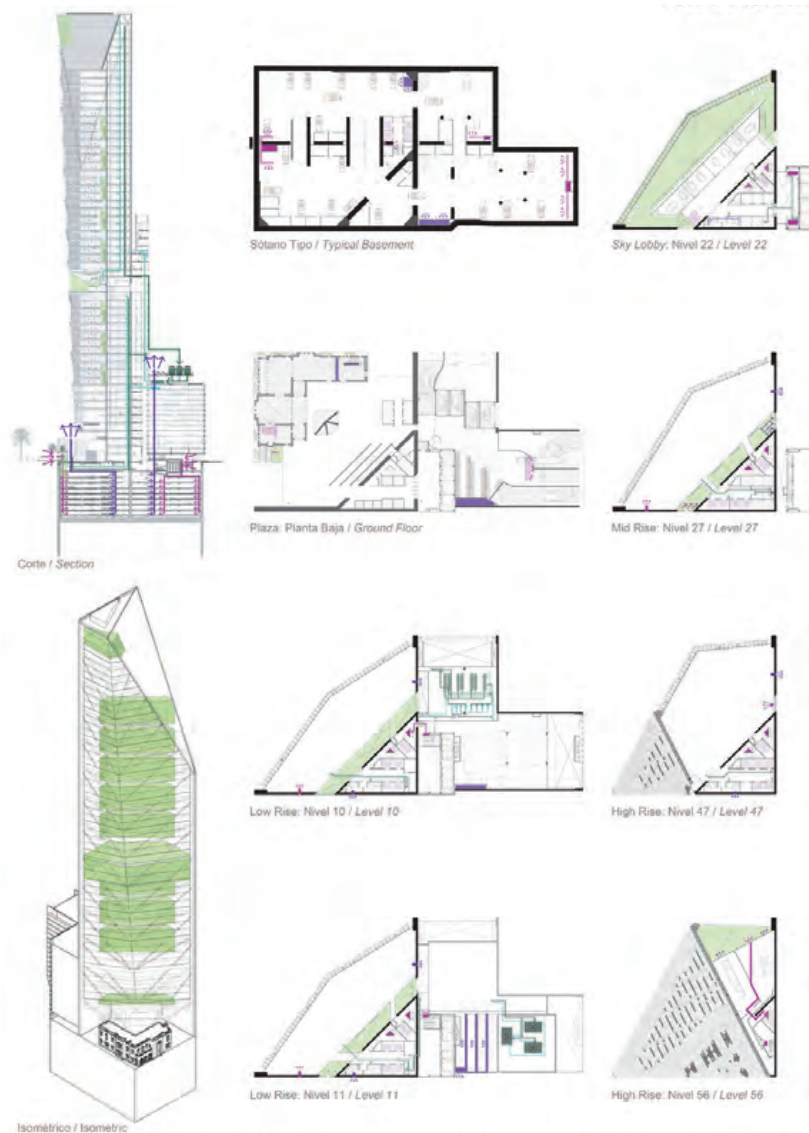

Figura 7. Flujos de Ventilación y Aire Acondicionado. Alfonso Merchand. 2016. LBR\&A (c) / Figure 7. Flow Ventilation and Air Conditioner. Alfonso Merchand. 2016. LBR\&A (๐.

best views of Chapultecpec Park, and increasing the efficiency of the upper level areas (Fig. 3).

This twist in the façade cantilevers 15 meters above a preserved historical house that surround the main lobby at street level. To preserve the brick and stone house, it was necessary to temporarily move it 14 meters in order to gain additional parking and commercial space under the house.

The clarity and strength of the architectural concept allow the project to incorporate the spatial and functionality layout of the building in a single concept, defined only by the three great walls. The served space (offices and other facilities), with its breath-taking views, has a unique spatiality due to zero structural columns, thus allowing a free adaptation of the final user needs, including the sports facility and other public spaces (Fig. 4).

Zero columns in its projects has been an important goal of LBR\&A work. This goal has been achieved by understanding façades as a construction element (frontier) that separates interior from exterior with the capacity to help the structure behaviour, rather than become a sterile additional weight that will demand additional structure, additional foundation, and additional cost for the building. By not having to be $100 \%$ transparent, a façade should work with 


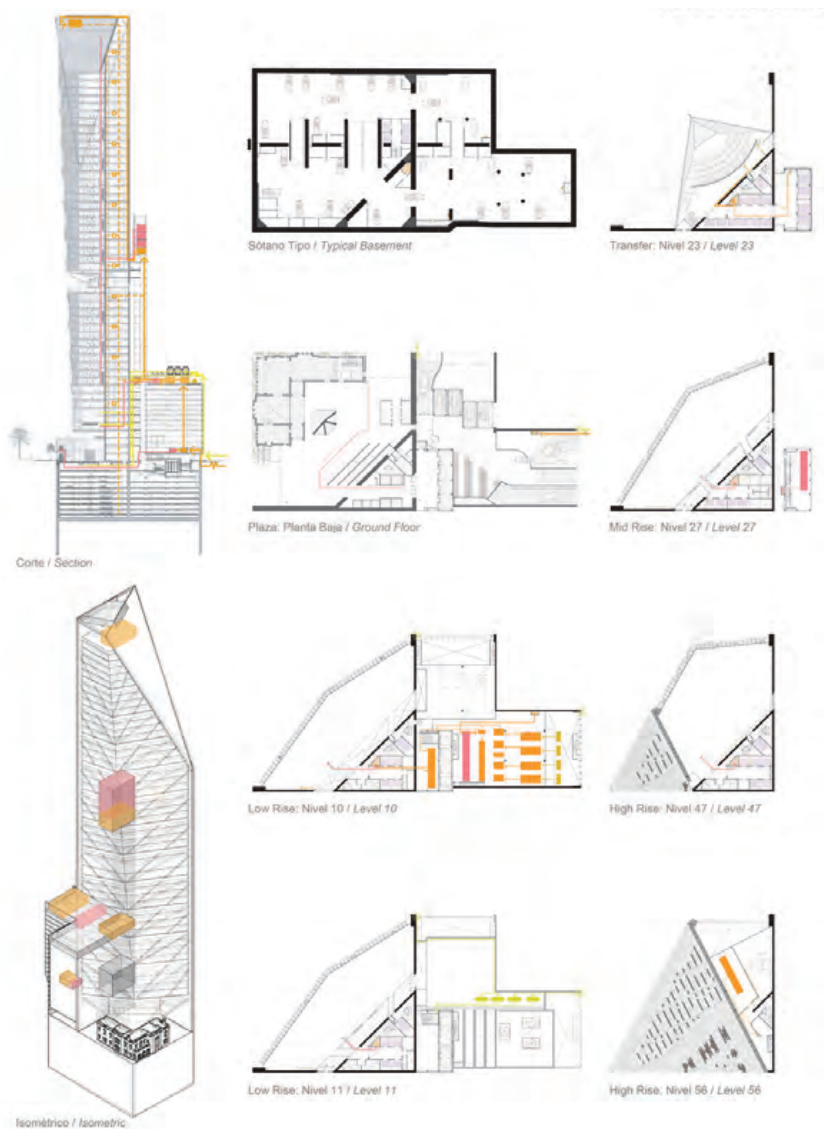

Figura 8. Flujos de Energía Eléctrica y Gas LP. L. Benjamín Romano (2016). OLBR\&A / Figure 8. Flow of Electric Energy. LP. L. Benjamín Romano (2016). OLBR\&A.

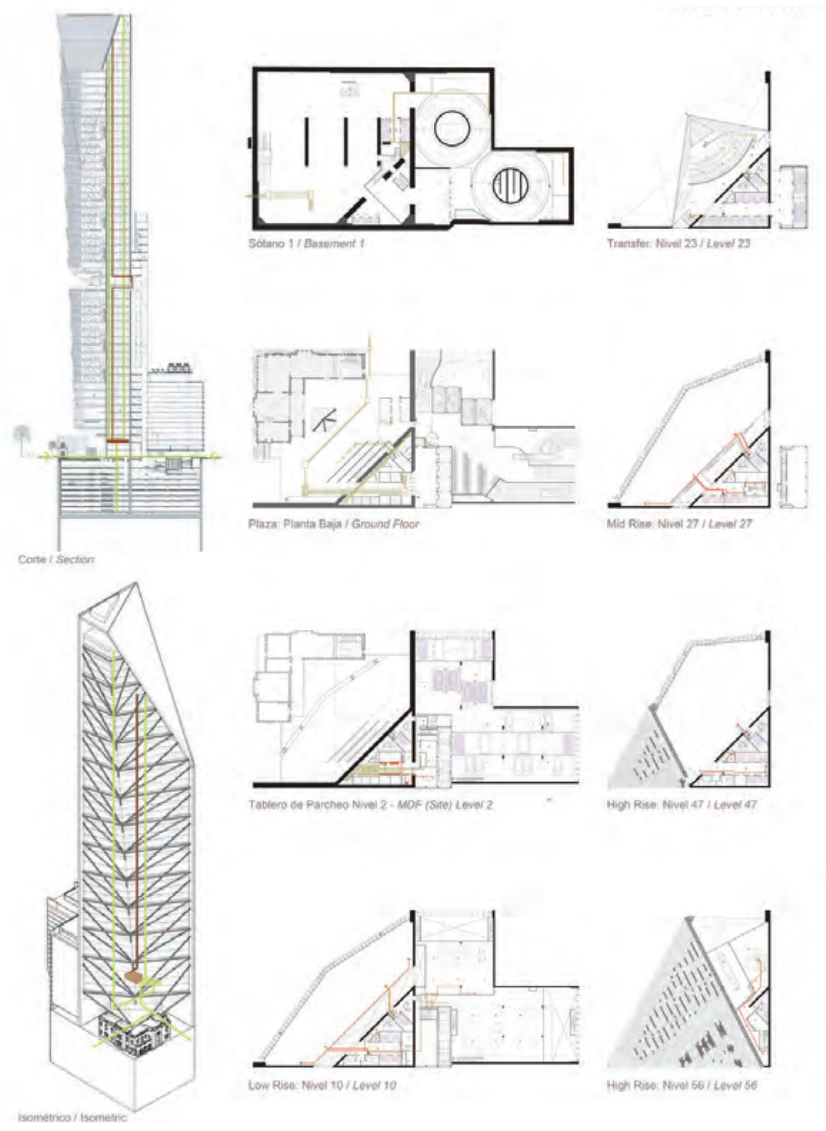

Figura 9. Flujos de Automatización, Voz y Datos. L. Benjamín Romano (2016). CLBR\&A Figure 9. Automation Flows, Voice and Data. L. Benjamín Romano (2016). CLBR\&A.

the structure instead of becoming a heavy and useless structural element. Vertical and horizontal structural flows have better performance with tectonic supporting structures - probably the reason why they are used in Mexican architecture.

Another Mexican concept that was incorporated into the building is the triple height patios with its typical cross ventilation concept. Every cluster has an individual garden for people to gather and relax, designed with natural light and ventilation flowing through the ripped concrete wall openings. The walls and the triple height patios are structurally designed to bend by releasing energy in a seismic event, while the fourth level of each cluster acts as a structural belt, integrating server and served spaces of the building (Fig. 5).

The Mexican patios are conceived as an extension of the horizontal public space at street level, and they allow natural air to flush for energy efficiency, responding to an understanding of wind performance (Fig. 6).

To properly understand the building's Flow, a CFD (Computational fluid dynamics) study was developed at Penn University of the proposed scheme (Fig. 7). 
332

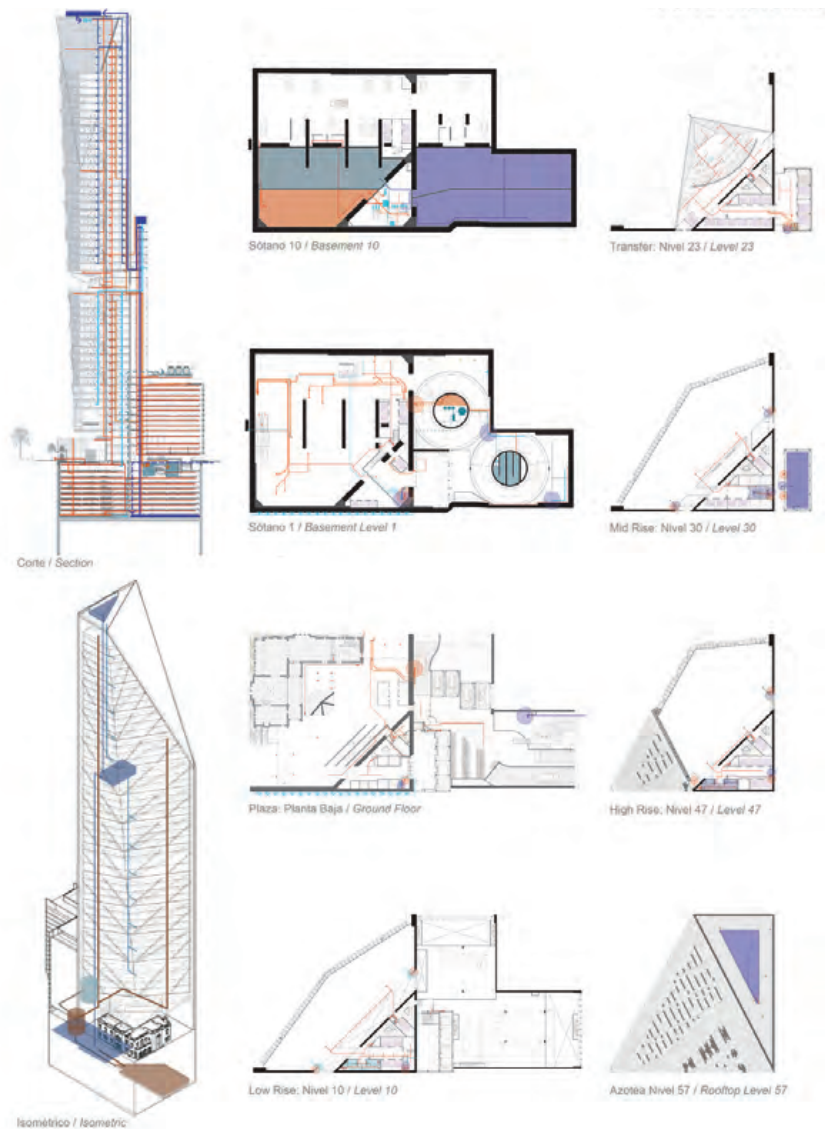

Figura 10. Flujo Hidrosanitario. L. Benjamín Romano (2016). @LBR\&A / Figure 10. Hydrosanitary Flow. L. Benjamín Romano (2016). CLBR\&A.

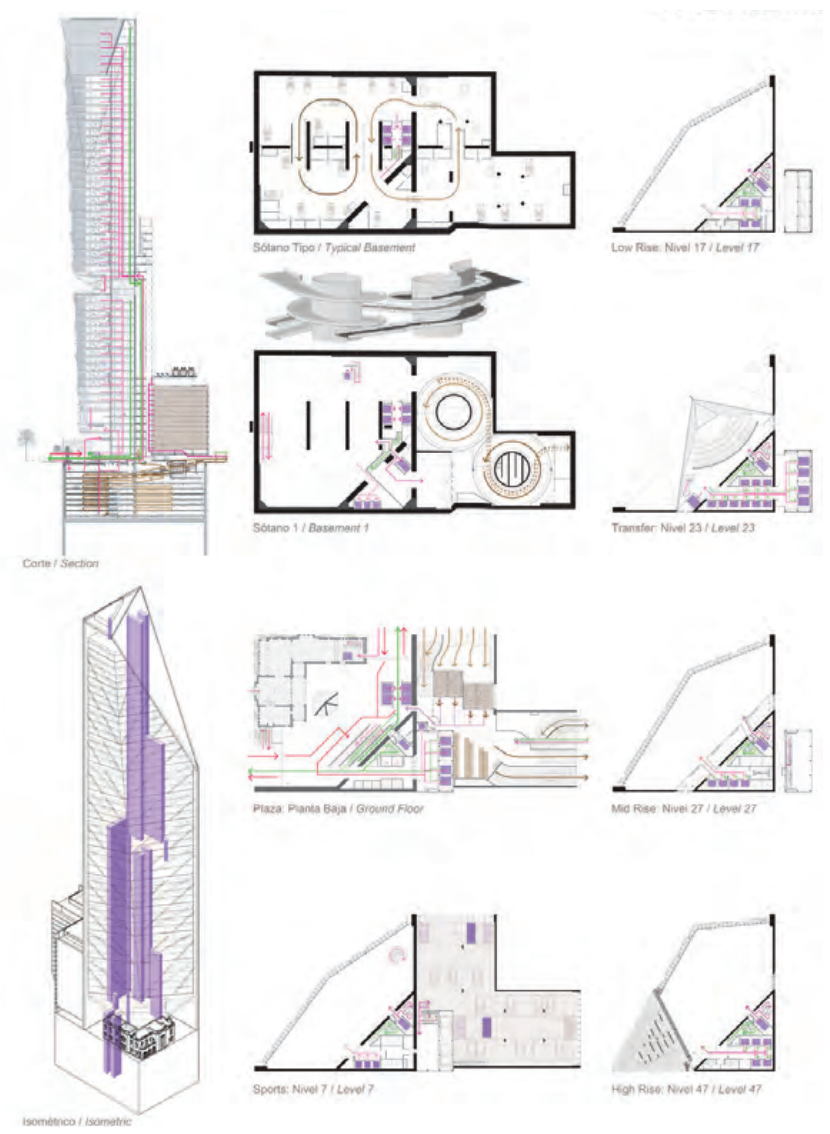

Figura 11. Flujos Peatonales y Vehiculares. L. Benjamín Romano (2016). @LBR\&A / Figure 11. Pedestrian Flow and Vehicles. L. Benjamín Romano (2016). OLBR\&A.

Each cluster works with its own compartmentalized MEP program to allow flow efficiency: 6 electrical substation transformers were installed throughout the building to convert 23,000V into 480V, and 14 small transformers were installed in each cluster to convert $480 \mathrm{~V}$ into $220 \mathrm{~V}$, minimizing the vertical duct area while maximizing the electrical conductor efficiency. The energy generators were designed to deliver energy in $23,000 \mathrm{~V}$, allowing the double electrical network (redundant) to be used when a city energy fail occurs (a common problem in Mexico City) (Fig. 8).

Voice and data are transmitted through two independent vertical ducts; one is used for building security purposes only, aligned to a series of totems that control the elevators, fire refuge and access control, and a second vertical duct manages the building and tenants' digital communications systems (Fig. 9).

Water (potable and in case of fire) are delivered through gravity, from three different water tank locations, minimizing the use of water pumps energy, while guaranteeing the water demand in case of fire event. A compartmentalized system of water reservoirs at basement 10 manages the potable, raw, pluvial and recycled waters, which are pumped to the different users and to the 30th and 57th floor level water tanks, which distribute the water needs according to 


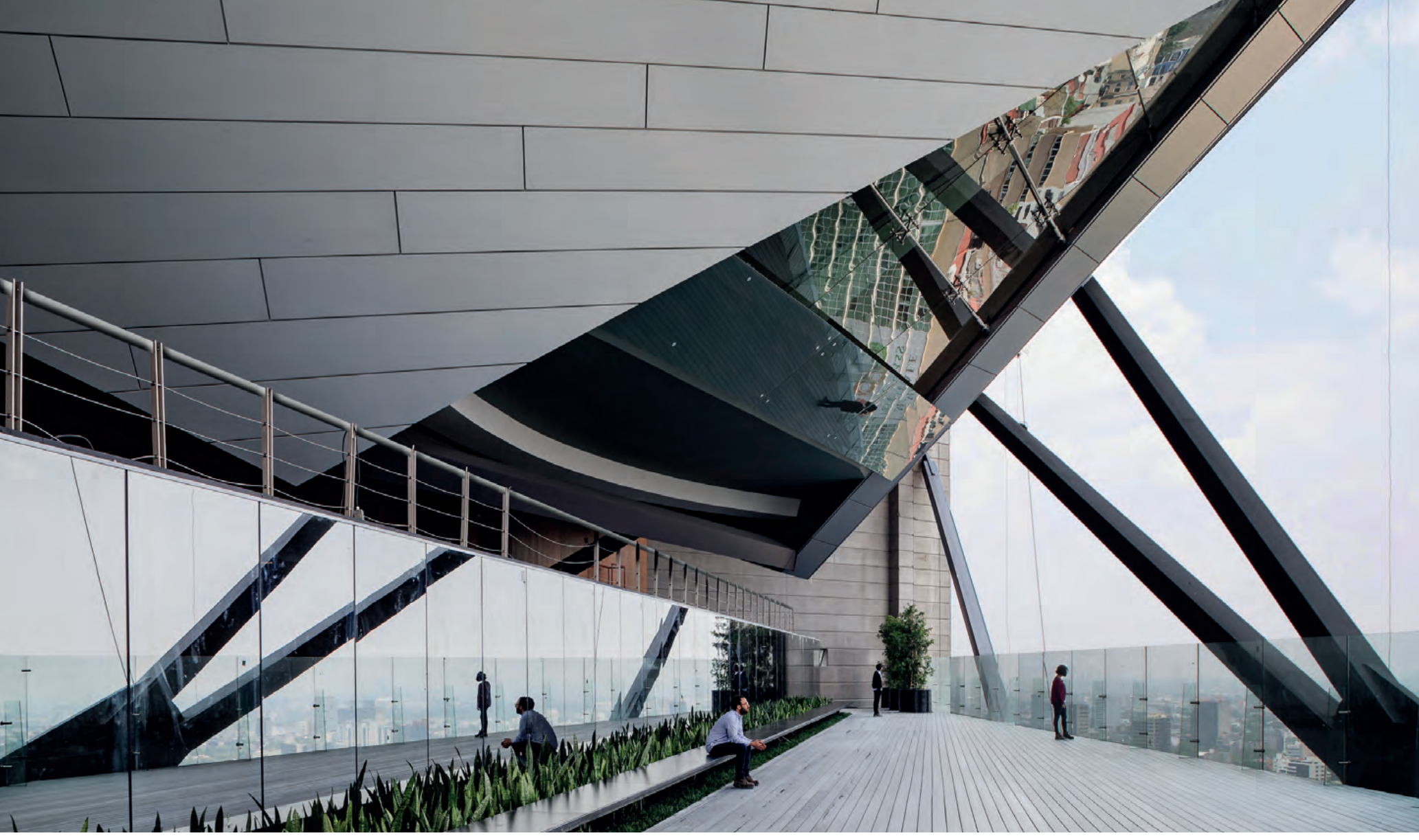

Figura 12a. Imágenes Generales. Alfonso Merchand (2016). CLBR\&A / Figure 12a. General Images. Alfonso Merchand (2016). CLBR\&A.

para ser reutilizadas en las torres de enfriamiento y mingitorios de los primeros 10 niveles (por requerimientos específicos de la certificación LEED), y para riego de jardinería reduciendo a cero la descarga de aguas residuales al sistema municipal de drenaje (Fig. 10).

La protección térmica de las tres fachadas minimiza la incidencia del flujo solar, reduciendo la demanda de agua helada del sistema de aire acondicionado, generada por tres equipos enfriadores (Chillers) de 433 TR cada uno, además de un equipo de 209 RT dedicado para dar servicio $7 / 24$ a los inquilinos en sus sistemas IT. El diseño contempla el uso eficiente del espacio, con una alta comprensión del impacto climático y del confort de sus habitantes, logrando una importante reducción del $25,4 \%$ en el consumo de energía, en comparación con edificios similares en la Ciudad de México. Gracias a esto, el edificio obtuvo la certificación PLATINUM LEED (máxima certificación) en 2016

Debido a un extraño código de la ciudad, 1100 plazas de aparcamiento tuvieron que ser integradas, comprometiendo el flujo eficiente de acceso y salida de los usuario. El acceso al estacionamiento de los sótanos funciona por dos calles distintas con una rampa de acceso permanente una rampa de salida permanente y una rampa bidireccional para ser utilizada alternativamente en las horas. Asimismo se instaló un sistema de estacionamiento height requirements. Sewage and rainwater are treated locally to be reused in the cooling towers, toilets (first 10 levels) and for gardening irrigation, reducing the sewage water discharge into the municipal drainage system to zero (Fig. 10).

The protected design of the three façades minimizes the solar flow incidence, thus reducing the demand of chilled water for the mechanical system. The total demand of the building - 1508 RT-is generated with three chillers of $433 \mathrm{RT}$ each, plus one additional joker chiller of 209 RT for a 7/24 IT dedicated service. The design contemplates the efficient use of space, with a high understanding of the climatic impact and the comfort of its dwellers, and a $25.4 \%$ reduction of energy consumption, compared to similar buildings in Mexico City. Thanks to this, the building obtained the PLATINUM LEED certification in 2016 from the USGB.

Due to a strange city code, 1100 parking spaces had to be included, compromising the efficient flow of user access and egress. The parking access was divided in two different streets, which comprise: a permanent access ramp to the basement parking levels, a permanent egress ramp from the basement parking levels, a bidirectional ramp from basements to be used alternately at rush hours and four robotic parking systems with independent access and egress equipment. 

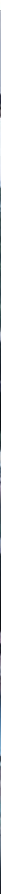

Figura 12b. Imágenes Generales. Alfonso Merchand (2016). OLBR\&A / Figure 12b. General Images. Alfonso Merchand (2016). (OLBR\&A.

robótico con servicio de cuatro equipos redundantes entre sí con accesos y salidas independientes.

El flujo peatonal accede al edificio desde dos calles diferentes, mientras que los servicios y residuos se manejan a través de la tercer calle. El edificio se divide en cuatro bloques diferentes de espacios: las instalaciones comerciales y deportivas; los clústers bajos de oficinas y los clústers medios y altos de oficinas. Los usuarios de los pisos altos y medios (High y Mid Rise) llegan al sky lobby del piso 23, a través de ascensores de alta velocidad, mientras que los usuarios de los cuerpos bajos (low rise) toman los elevadores en el primer piso. Las instalaciones deportivas y el área comercial utilizan accesos diferentes desde la calle al núcleo de elevadores (Fig. 11).

Dada la altura del edificio y en respuesta al estudio de egresos, se instalaron elevadores que funcionan en caso de incendio, por lo que se acondicionaron refugios contra incendio a la entrada de cada grupo de elevadores en los niveles de oficinas. Las escaleras de emergencia con su refugio de incendios, los cubos de ascensores, los baños públicos y los ductos verticales de las instalaciones MEP, comparten la misma columna vertical del espacio servidor, definido desde el Partido Arquitectónico. Los ascensores high rise y shuttle son los únicos con equipos de alta velocidad en el edificio, que en conjunto permitieron un reducido consumo energético de $281.9 \mathrm{~kW}$ de todos los elevadores.
Pedestrian flow enters the building from two different streets, while services and waste are managed through the third street. The building is divided into four different blocks for users: commercial and sports facilities, and high, medium, and low rise levels. The high and medium rise users are delivered to a sky lobby at the 23rd floor, through high-speed shuttle elevators, while low rise users take an elevator at mezzanine level. The sports facility and the commercial area use a different street access to the elevators core. Two pressurized emergency stairs and a fire refuge are located at each level, next to the elevators, and they are designed to activate during such an event (Fig. 11).

The emergency stairs with their fire refuge, the elevators shafts, the public toilets, and the vertical MEP ducts share the same vertical spine throughout the building (Core), defined from the original architectural parti. The high, mid, and low elevator blocks, the public toilets, and the MEP closets shift location from block to block, increasing the energy performance of the 29 elevators that run throughout the building. The high rise and shuttle elevators are the only equipment designed with high speed machinery, reducing the total elevators energy consumption to $281.9 \mathrm{KW}$.

The Tower construction process can be read as an intrinsic part of the project façade, which responds to the poured concrete casting process, the views, the mechanical and ventilation openings, and to 


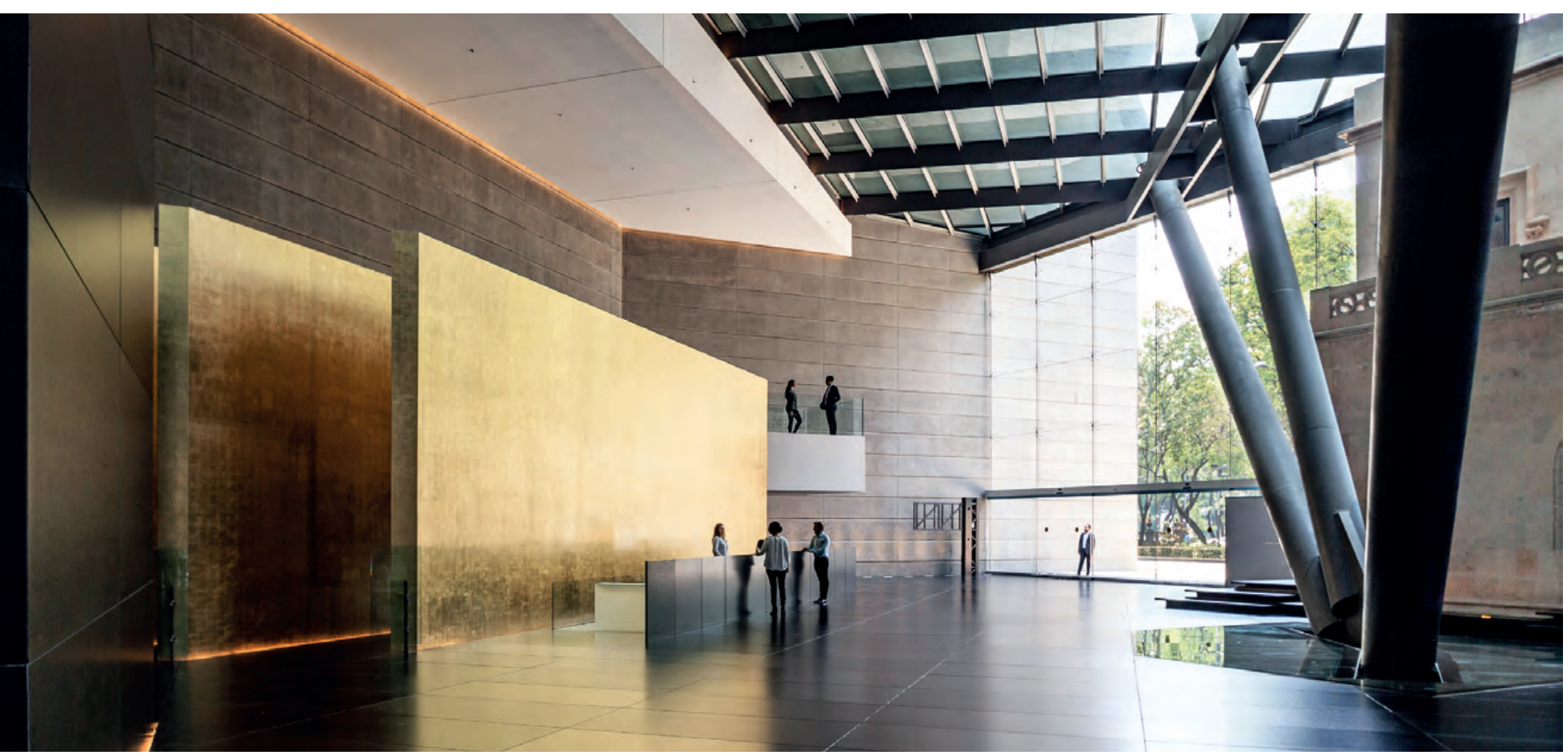

Figura 12c. Imágenes Generales. Alfonso Merchand (2016). OLBR\&A / Figure 12c. General Images. Alfonso Merchand (2016). @LBR\&A.

El proceso de construcción de la torre puede ser entendido como una parte integral del diseño arquitectónico y estructural, con una clara respuesta al proceso de colado, a las visuales y aberturas necesarias para los equipos mecánicos. La fragmentación del proceso de colado de los muros expuestos permite al concreto direccionar las grietas que se pudieran generar por tensiones sísmicas del material.

La concepción del espacio y estructura, el proceso de construcción y la complejidad del proyecto, por la pequeña huella del edificio, son visibles tanto en el exterior como en el interior en una armoniosa convivencia volumétrica, donde la arquitectura es estructura y es comportamiento energético.

\section{Conclusiones}

El deseo humano de vivir en un contexto urbano inevitablemente aumentará el uso de la tipología de los rascacielos.

Los diseñadores de rascacielos han estado obsesionados con la imagen acristalada de los edificios, dando poca atención al comportamiento energético y de flujos en los edificios. Tales acciones afectan la eficiencia energética y estructural, el confort humano y la calidad del espacio interior y exterior, elevando por consecuencia el costo inicial de la construcción, y el mantenimiento permanente del edificio. the possible punctual cracks that may occur in the concrete when tensional seismic stresses happen in the future.

The conception of space and structure, the construction process, and the complexity of the project due to the small footprint of the building are visible both in the exterior and interior, with a harmonious coexistence with the volume, where architecture is structure and is energy behaviour.

\section{Conclusions}

The human desire to live in an urban context will inevitably increase the use of the Skyscraper typology.

Unfortunately, skyscraper designers have been obsessed with the all- glass final image of the buildings, with little action on the flow behaviour through the building.

Such actions affect the energy and structure efficiency, the people comfort, the quality of the internal and external space, and consequently the initial construction cost and maintenance of the building.

The good understanding of the architectural concept, based on its flows, form, context, and structural integration, as well as a good interpretation of the local and vernacular architecture, may help to achieve the 2030 net zero energy buildings goal (Fig. 12). 


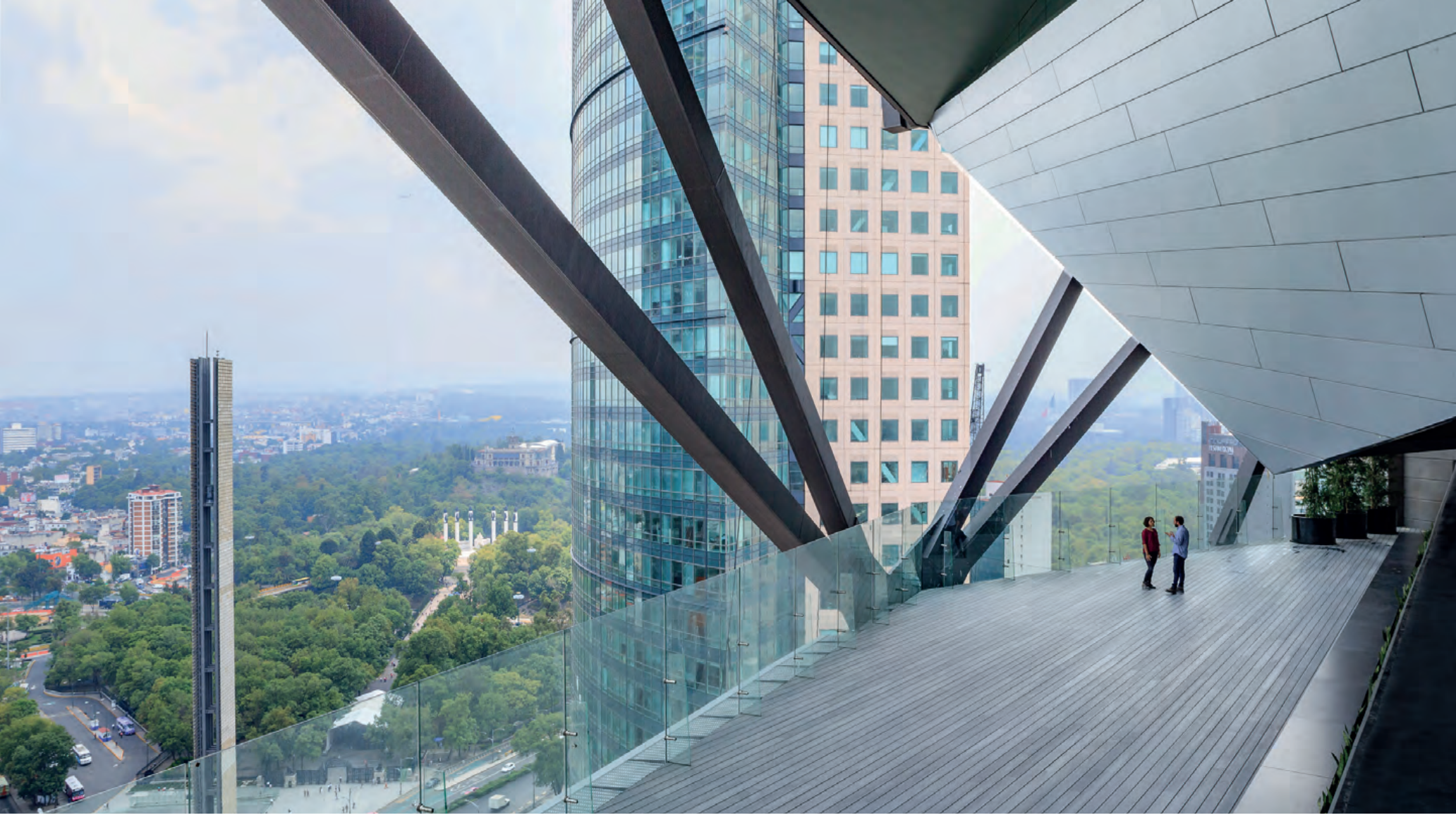

Figura 12e. Imágenes Generales. Alfonso Merchand (2016). CLBR\&A / Figure 12e. General Images. Alfonso Merchand (2016). CLBR\&A.

primer edificio de su historia junto con la carrera de arquitectura. Interesado en la industrialización de la vivienda, se contrató en una fábrica en el Estado de Israel, donde entendió dos cosas: Que su oficio nunca sería la construcción masiva de la arquitectura, y que ésta se diseña pensando en su estructura y proceso constructivo. En 1982, al presentar su examen profesional obtuvo Mención Honoríica, y fue invitado por sus sinodales a dar clases en la Universidad, donde ha sido Profesor del ciclo de Proyectos y de Construcción; ha impartido Diplomados, participado en la Coordinación del Ciclo de Construcción, y en la revisión del plan de estudios de la Escuela de Arquitectura Plan UIA, y desde el año 2003, -invitado por el Arquitecto Francisco Serrano- ha coordinado la Cátedra Blanca Cemex en la universidad. Su formación universitaria, su temprano entendimiento de las estructuras y procesos constructivos, así como con su continuo aprendizaje del oficio a través de la docencia, son claramente visibles en sus proyectos, que le han merecido reconocimientos internacionales, tales como: 2016 - 2017: Invitado como "Expert in Residence" por la Universidad Harvard. 2016: Medalla de Oro en la XIV Bienal Nacional de Arquitectura Mexicana / Premio Diamante ACEC de New York en la Categoría "C" Sistemas Estructurales /"Arquitectura Corporativa". Premio Noldi Schreck, Revista Glocal / La Obra del año 2016. Revista "Obras". Grupo Editorial Expansión. 2014: Premio Augusto A. Álvarez. Otorgado por excelencia en su trayectoria arquitectónica. FCARM Federación de Colegio de Arquitecto de México / XIII Bienal Nacional de Arquitectura Mexicana: Medalla de Plata por la Categoría "E", Educación / PCI Design Awards Program Category Education. 2012: Medalla de Plata en la Bienal Mexicana por Innovación Tecnológica en la categoría Recuperación del Patrimonio Inmobiliario. 2011: Premio Luis Barragán al Mérito Profesional en Práctica Profesional en Arquitectura /Premios CAM-SAM. 2010: Medalla de Plata en la Bienal Mexicana por el proyecto Torre Tres Picos, en la categoría de Oficinas; XI Bienal de Arquitectura Mexicana. 1992: Primer lugar Mundial al edificio inteligente otorgado por el IBI de Chicago Illinois USA. recognition, such as: 2016 - 2017: Invited as "Expert in Residence" by Harvard University. 2016: Gold Medal at the XIV National Biennial of Mexican Architecture / ACEC Diamond Award of New York in Category "C" Structural Systems / "Corporate Architecture". Noldi Schreck Award, Glocal Magazine / The Work of the year 2016. Magazine "Works". Expansion Editorial Group. 2014: Augusto A. Alvarez Award. Awarded for excellence in his career architectural FCARM Federation of the College of Architects of Mexico / XIII National Biennial of Mexican Architecture: Silver Medal for Category "E", Education / PCI Design Awards Program Category Education. 2012: Silver Medal in the Mexican Biennial for Technological Innovation in the category of Real Estate Property Recovery. 2011: Luis Barragan Prize for Professional Merit in Professional Practice in Architecture; CAM-SAM Awards. 2010: Silver Medal at the Mexican Biennial for the Torre Tres Picos project, in the category of Offices / XI Biennial of Mexican Architecture. 1992: First place in the intelligent building awarded by the IBI of Chicago Illinois USA. 